\title{
HUBUNGAN TINGKAT PENDIDIKAN DAN TINGKAT PENGETAHUAN DENGAN UPAYA PENCEGAHAN DEMAM BERDARAH DENGUE PADA MASYARAKAT DUKUH KARANGANYAR BUGEL POLOKARTO KARANGANYAR
}

\author{
Budi Herminto ${ }^{1}$, Wiwin Winarni ${ }^{2}$, Yosan Misoni ${ }^{3}$
}

\begin{abstract}
Background : based on survey reported by Public Health Center at Polokarto on 2015, the incidence of DHF was increased accounted for $21.43 \%$ including people in Karanganyar. Early interview conducted on June 2015 revealed that there were 4 people who suffered from DHF. The observation showed that the sanitation of the environment was much dirty. There were a lot of cans which used as mosquito nests. Some people in that region reported that they have not yet to do prevention against DHF effectively.

The purpose of this study was to analyze the correlation between the education level and level of knowledge about DHF of people towards the efforts of DHF preventions.

Methods : this research used analytic with correlation design. The total population involved in this research were 150 people of Karanganyar region. Sampling technik used was total sampling. Data was collected by using questionnaire and observing the behaviour of the people to collect data of prevention efforts. The data was analyzed using logistic regression aided by SPSS serial 16 .

Results of this study : 1) The majority people of Karanganyar had high level of knowledge account for $96 \%$. 2)The majority people had high level of education account for $65,33 \%$. 3) The majority people in Karanganyar had performed less effective of the efforts of DHF preventions $(76 \%)$. 4) Level of knowledge $(\mathrm{OR}=1,611)$ has stronger correlation than level of education $(\mathrm{OR}=0,034)$ towards the efforts of DHF prevention.

Conclusion : that education level dan knowledge level have significant correlation toward the efforts of DHF prevention.
\end{abstract}

Keywords: level of knowledge, level of education, the efforts of DHF preventions

\section{PENDAHULUAN}

Penyakit Demam Berdarah Dengue (DBD) adalah penyakit yang disebabkan oleh virus Dengue I, II, III dan IV yang ditularkan oleh nyamuk Aedes Aegypti dan Aedes Albopictus. Penyakit demam berdarah dengue memiliki gejala kesadaran menurun, demam selama 5 sampai 7 hari, muncul bintik-bintik merah, kulit tangan lembab, kencing berkurang, nafsu makan hilang (Soegijanto, 2006).

Menurut Direktorat Pengendalian Penyakit Bersumber Binatang (Dir P2B2), Kementerian Kesehatan Republik Indonesia, pada tahun 2010 Indonesia memiliki kasus DBD tertinggi di ASEAN dengan 150.000 kasus dan 1.317 orang meninggal akibat penyakit ini. Kasus demam berdarah di Indonesia tercatat masih tinggi bahkan paling tinggi dibanding negara lain di ASEAN. Sebagian besar kabupaten di Sukoharjo, Jawa Tengah merupakan daerah endemis demam berdarah dengan jumlah penderita hampir meningkat setiap tahunnya (Puspitasari dan Susanto, 2011).

Menurut catatan Dinas Kabupaten Sukoharjo, pada tahun 2007 terdapat 184 kasus demam berdarah yang terjadi di Sukoharjo. Sementara tahun 2008 terdapat 367 kasus demam berdarah. Jumlah ini mengalami peningkatan yang hampir mencapai $100 \%$ dibanding tahun lalu. Diketahui pula bahwa pada tahun 2010 terdapat 434 kasus demam berdarah. Hasil penelitian di Kelurahan Malalayang 
menurut penelitian Puspitasari dan Susanto (2011) menunjukkan bahwa salah satu faktor penyebab tingginya kasus DBD di Manado adalah kurangnya pengetahuan dan sikap masyarakat sehingga berdampak pada perilaku masyarakat dalam pencegahan DBD. Dari segi biologis perilaku adalah suatu kegiatan atau aktivitas organisme yang bersangkutan. Perilaku kesehatan adalah suatu respon seseorang terhadap stimulus atau objek yang berkaitan dengan sakit dan penyakit, sistem pelayanan kesehatan, makanan dan minuman, serta lingkungan. Pengetahuan adalah hasil dari tahu dan ini terjadi setelah orang melakukan pengindraan terhadap suatu obyek tertentu. Dari pengalaman dan penelitian terbukti bahwa perilaku yang didasari oleh pengetahuan akan lebih langgeng daripada perilaku yang tidak didasari oleh pengetahuan. Pengetahuan tersebut meliputi bagaimana tingkat pengetahuan dari warga untuk melakukan pencegahan Demam Berdarah Dengue (Notoatmodjo, 2007). Erfandi (2009) menjelaskan bahwa salah satu faktor yang berpengaruh terhadap pengetahuan adalah pendidikan. Pengetahuan sangat erat hubungannya dengan pendidikan, semakin tinggi jenjang pendidikan yang dicapai semakin banyak pula pengetahuan yang didapatkan oleh individu.

Pencegahan DBD perlu dilakukan antara lain dengan menghindari gigitan nyamuk disiang hari karena nyamuk Aedes Aegypti aktif disiang hari, gunakan cairan atau krim anti nyamuk, buang dan timbuni bendabenda yang tidak berguna yang dapat menampung air, semprot sudut-sudut rumah dan halaman yang merupakan tempat berkeliaran nyamuk dengan obat semprot nyamuk (Misnadiarly, 2009).
Berdasarkan laporan dari Puskesmas Polokarto tahun 2015, angka kejadian DBD di Karanganyar, Bugel, tergolong cukup tinggi, dimana kasus DBD mencapai 21,43\%. Dukuh Karanganyar merupakan salah satu dukuh yang berada di Kelurahan Bugel Kecamatan Polokarto Kabupaten Sukoharjo. Hasil wawancara awal dengan 10 warga diperoleh 4 kasus DBD pada bulan Juni 2015 di dukuh tersebut. Hasil observasi penulis didapatkan tempat tinggal warga yang kurang bersih dan masih banyak kaleng-kaleng bekas yang tidak dibuang sehingga bisa menjadi sarang nyamuk. Beberapa warga melaporkan belum melakukan tindakan pencegahan DBD. Warga menyebutkan jarang mendapatkan penyuluhan tentang DBD.

Berdasarkan uraian di atas, penulis tertarik untuk melakukan penelitian "Hubungan tingkat pendidikan dan tingkat pengetahuan tentang Demam Berdarah Dengue dengan upaya pencegahan Demam Berdarah Dengue pada masyarakat Dukuh Karanganyar".

\section{TUJUAN PENELITIAN}

Secara umum penelitian ini bertujuan untuk mengetahui hubungan antara tingkat pendidikan dan tingkat pengetahuan DBD dengan upaya pencegahan DBD pada masyarakat Polokarto Sukoharjo. Secara khusus penelitian ini bertujuan untuk mengetahui tingkat pendidikan masyarakat, mengetahui tingkat pengetahuan masyarakat tentang DBD, mengetahui hubungan antara tingkat pendidikan dengan upaya pencegahan DBD serta mengetahui hubungan antara tingkat pengetahuan tentang DBD dengan upaya pencegahan DBD. 


\section{DESAIN PENELITIAN}

Penelitian ini merupakan bentuk penelitian analitik dengan desain korelasi untuk mengetahui hubungan tingkat pengetahuan tentang DBD dan tingkat pendidikan dengan upaya pencegahan DBD. Pengumpulan data dilakukan dengan menggunakan kuesioner dan melakukan observasi. Analisa multivariat yang digunakan dalam penelitian ini adalah regresi logistik ganda.

\section{POPULASI, SAMPEL DAN TEHNIK SAMPLING}

Populasi pada penelitian ini adalah seluruh masyarakat Dukuh Karanganyar berjumlah 150 orang. Teknik sampling yang digunakan adalah teknik total sampling.

\section{HASIL PENELITIAN}

Berdasarkan penelitian yang telah dilakukan diketahui hasil penelitian mengenai hubungan tingkat pengetahuan tentang DBD dan tingkat pendidikan dengan upaya pencegahan DBD yaitu sebagai berikut :

Tabel 1.

Distribusi Frekuensi Tingkat

Pengetahuan, Tingkat Pendidikan dan Upaya Pencegahan DBD

\begin{tabular}{|c|c|c|c|}
\hline $\begin{array}{c}\text { Variabel } \\
\text { Independen }\end{array}$ & Kategori & $f$ & $\%$ \\
\hline Tingkat & Rendah & 6 & 4 \\
\hline Pengetahuan & Tinggi & 144 & 96 \\
\hline Tingkat & Dasar & 52 & 34.7 \\
\hline Pendidikan & Lanjut & 98 & 65.3 \\
\hline $\begin{array}{c}\text { Upaya } \\
\text { Pencegahan }\end{array}$ & $\begin{array}{c}\text { Efekfif } \\
\text { Kurang } \\
\text { Efektif }\end{array}$ & $\begin{array}{c}36 \\
114\end{array}$ & $\begin{array}{l}24 \\
76\end{array}$ \\
\hline
\end{tabular}

Berdasarkan tabel 1 didapatkan bahwa mayoritas warga Dukuh Karanganyar mempunyai tingkat pengetahuan yang tinggi sebanyak 144 warga (96\%). Warga sebagian besar mempunyai tingkat pendidikan lanjut sejumlah 98 warga (65.3\%). Upaya pencegahan DBD yang selama ini dilakukan masuk dalam kategori kurang efektif (76\%). Hasil analisis bivariat menunjukkan tidak terdapat hubungan antara tingkat pengetahuan dan upaya pencegahan DBD (OR 3.235; Cl $95 \% \quad 0.624$ hingga 16.777 ; $\mathrm{p}=0.142$ ). hal tersebut menunjukkan terdapat hubungan antara tingkat pendidikan dengan upaya pencegahan DBD. Warga dengan tingkat pendidikan lanjut memiliki kemungkinan efektif dalam melakukan upaya pencegahan DBD 28,038 kali lebih tinggi daripada warga dengan tingkat pendidikan dasar (OR 28.038; Cl 95\% 9.763 hingga $80.524 ; p=0.000$ ).

Tabel 2.

Hasil Analisa Regresi Logistik

\begin{tabular}{|c|c|c|c|c|}
\hline \multirow{2}{*}{$\begin{array}{c}\text { Variabel } \\
\text { Independen }\end{array}$} & \multirow[b]{2}{*}{ OR } & \multicolumn{2}{|c|}{$\mathrm{Cl} 95 \%$} & \multirow[b]{2}{*}{$p$} \\
\hline & & $\begin{array}{l}\text { Batas } \\
\text { Bawah }\end{array}$ & $\begin{array}{c}\text { Batas } \\
\text { Atas }\end{array}$ & \\
\hline $\begin{array}{l}\text { Tingkat } \\
\text { pengetahuan } \\
\text { tinggi }\end{array}$ & 1.611 & 0.293 & 8.863 & 0.584 \\
\hline $\begin{array}{l}\text { Tingkat } \\
\text { pendidikan } \\
\text { tinggi }\end{array}$ & 0.034 & 0.012 & 0.99 & 0.000 \\
\hline $\begin{array}{l}\text { Nagelkerke } \\
R \text { Square }\end{array}$ & $47.2 \%$ & & & \\
\hline
\end{tabular}

Tabel 2 menunjukkan terdapat hubungan yang positif dan tidak signifikan secara statistik antara tingkat pengetahuan dan keefektifan upaya pencegahan DBD. Kecederungan warga dengan tingkat pengetahuan tinggi melakukan upaya pencegahan DBD secara efektif 1.161 kali dari warga dengan tingkat pengetahuan rendah (OR=1.611; Cl95\% 0.293 hingga 8.863; $\quad \mathrm{p}=0.584)$. Terdapat hubungan yang negatif namun signifikan secara statistik antara tingkat pendidikan dengan keefektifan upaya pencegahan DBD $(\mathrm{OR}=0.034 ; \mathrm{Cl} 95 \% 0.012$ hingga $0.99 ; p=0.000$ ). 
PEMBAHASAN

1. Hubungan antara Tingkat Pengetahuan tentang DBD dengan Upaya Pencegahan DBD Dari hasil analisis bivariat menggunakan Chi Square didapatkan hasil $p=0.142$, dapat diartikan bahwa tidak ada hubungan antara tingkat pengetahuan dengan upaya pencegahan DBD. Hal ini dibuktikan dengan mayoritas warga Dukuh Karanganyar berpendidikan lanjut sebanyak $65.3 \%$ namun upaya pencegahan DBD yang dilakukan belum efektif sebanyak $76 \%$. Berdasarkan hasil observasi terhadap upaya pencegahan DBD yang telah dilakukan, warga tersebut belum melakukan semua komponen perilaku yang termasuk dalam tindakan PSN (Pemberantasan Sarang Nyamuk) meliputi perilaku menguras bak air, menutup tempat penampungan air, mengubur barang-barang bekas, dan menggunakan bahan anti nyamuk. Hasil observasi menunjukkan mayoritas warga tersebut hanya melakukan dua atau tiga komponen dari upaya PSN.

Rogers sebagaimana dikutip oleh Fitriani (2011), menjelaskan bahwa terdapat beberapa proses yang terjadi secara berurutan sebelum seseorang mengadopsi perilaku baru yang meliputi awarness, interest, evaluation, trial dan adoption. Jika proses tersebut berjalan dengan baik maka perilaku yang dihasilkan dengan didasari pengetahuan akan lebih langgeng.

Teori tersebut selaras dengan penelitian yang dilakukan oleh Silowati, Arifah dan Zulaicha (2012), mengenai hubungan tingkat pengetahuan tentang merokok terhadap frekuensi merokok pada remaja awal Desa

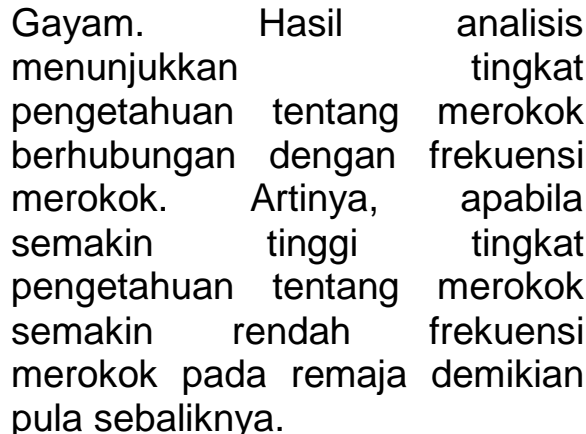

Pada penelitian ini ditemukan adanya ketidaksesuaian antara tingkat pengetahuan warga dengan keefektifan upaya pencegahan DBD. Hal ini dapat terjadi akibat adanya proses adopsi perilaku yang diduga tidak berjalan dengan baik. Notoatmodjo (2007) menjelaskan bahwa perubahan atau proses adopsi perilaku merupakan suatu proses yang kompleks dan memerlukan waktu yang relatif lama. Secara teori terdapat tiga tahapan perubahan perilaku yaitu pengetahuan, sikap dan praktik/tindakan yang terjadi secara berurutan. Namun, beberapa penelitian menyebutkan bahwa dalam kehidupan sehari-hari proses tersebut tidak selalu berurutan seperti teori. Artinya, seseorang telah berperilaku positif meskipun pengetahuan dan sikapnya masih negatif. Begitu pula sebaliknya, seseorang mungkin berperilaku negatif meskipun pengetahuan dan sikapnya sudah positif.

Dari paparan teori tersebut sangat dimungkinkan terdapat faktor-faktor lain yang dapat mempengaruhi perilaku warga dalam melakukan upaya pencegahan DBD. Warga dengan tingkat pengetahuan yang tinggi mengenai DBD dapat mempunyai motivasi dan minat yang rendah dalam melakukan perilaku upaya pencegahan DBD.

2. Hubungan antara Tingkat Pendidikan dengan Upaya Pencegahan DBD 
Dari hasil analisis bivariat menggunakan uji Chi Square didapatkan hasil $p=0.000$, menunjukkan adanya hubungan antara tingkat pendidikan dengan keefektifan upaya pencegahan DBD. Menurut UU Nomor 20 Tahun 2003, pendidikan adalah usaha sadar dan terencana untuk mewujudkan suasana belajar dan proses pembelajaran agar peserta didik secara aktif mengembangkan potensi dirinya untuk memiliki kekuatan spiritual keagamaan, pengadilan diri, kepribadian, kecerdasan, akhlak mulia, serta ketrampilan yang diperlukan dirinya, masyarakat, bangsa dan negara (Hasbullah, 2009). Semakin tinggi tingkat pendidikan seseorang maka akan semakin mudah menerima informasi yang pada akhirnya akan mempengaruhi perilaku individu tersebut termasuk perilaku dalam upaya mencegah DBD. Hal ini dibuktikan dengan hasil penelitian ini, bahwa mayoritas warga Dukuh Karanganyar masuk dalam kategori berpendidikan lanjut (SMA/ Perguruan Tinggi) sebanyak 97 warga (64.67\%). Jumlah warga dengan tingkat pendidikan lanjut dan melakukan upaya pencegahan DBD secara efektif sebanyak 92 warga dan 5 warga masuk dalam kategori kurang efektif.

Slameto (2015), mengungkapkan bahwa faktor sekolah dapat mempengaruhi proses belajar. Faktor-faktor tersebut mencakup metode belajar, kurikulum, relasi guru dengan siswa, relasi siswa dengan siswa, disiplin sekolah, pelajaran dan waktu sekolah, standar pelajaran, keadaan gedung, metode belajar dan tugas rumah. Jika dikaitkan dengan paparan teori tersebut maka individu dengan tingkat pendidikan yang tinggi akan memberikan beberapa perbedaan terhadap individu yang masuk dalam kategori tingkat pendidikan rendah. Perbedaan tersebut dapat berupa perbedaan metode belajar, perbedaan kurikulum yang pernah didapatkan, standar pelajaran dan bagaimana individu terlibat dalam proses belajar mandiri dan proses penerimaan informasi baru.

3. Hubungan antara Tingkat Pengetahuan dan Tingkat Pendidikan terhadap Upaya Pencegahan DBD

Hasil analisa multivariat pada tabel 2 menunjukkan variabel independen secara bersamasama mempengaruhi variabel dependen yang dapat dilihat dari nilai Nagelkerke $R$ Square : $47,2 \%$, sedangkan $53,8 \%$ dijelaskan oleh faktor-faktor yang lain di luar variabel penelitian. Variabel independen yang dimasukkan dalam penelitian ini adalah tingkat pengetahuan tentang DBD dan tingkat pendidikan sedangkan variabel dependen adalah upaya pencegahan DBD. Notoatmodjo (2007) menjelaskan faktor-faktor yang memegang peranan di dalam pembentukan perilaku dapat dibedakan menjadi dua yaitu faktor intern dan faktor ekstern. Faktor intern berupa kecerdasan, persepsi, motivasi, minat, emosi dan sebagainya untuk mengolah pengaruhpengaruh dari luar. Sedangkan faktor ekstern meliputi objek, orang, kelompok dan hasil-hasil kebudayaan yang dijadikan sasaran dalam mewujudkan bentuk perilakunya.

Dari hasil analisa multivariat didapatkan informasi bahwa variabel tingkat pengetahuan mempunyai pengaruh yang lebih tinggi $(\mathrm{OR}=1,611) \quad$ daripada variabel tingkat pendidikan 
(OR=0,034). Slameto (2015), menyebutkan bahwa dalam proses belajar yang bermakna, untuk mencapai pengertianpengertian baru dan retensi yang baik, materi-materi belajar selalu dan hanya dapat dipelajari bila dihubungkan dengan konsepkonsep, prinsip-prinsip serta informasi-infromasi yang relevan yang telah dipelajari sebelumnya. Substansi serta sifat organisasi latar belakang pengetahuan ini mempengaruhi ketepatan serta kejelasan dan kemampuan memperoleh kembali pengertianpengertian baru tersebut. Dari paparan teori tersebut dapat dijelaskan bahwa tingkat pengetahuan mempunyai peran yang signfikan dalam membentuk struktur kognitif dalam mempelajari pengetahuan baru.

Erfandi (2009), menyebutkan bahwa salah satu faktor yang dapat mempengaruhi tingkat pengetahuan adalah pendidikan. Pengetahuan sangat erat hubungannya dengan pendidikan, karena diharapkan dengan semakin tinggi jenjang pendidikan yang dicapai semakin banyak pula pengetahuan yang didapat. Jadi dapat disimpulkan bahwa secara bersama-sama tingkat pengetahuan mempunyai pengaruh yang lebih kuat dibandingkan tingkat pendidikan. Hasil penelitian ini sesuai dengan penelitian yang dilakukan oleh Ambarwati, Sutrisna dan Setiyadi (2013), mengenai hubungan tingkat pendidikan dan tingkat pengetahuan dengan kepatuhan pengguna pil KB. Analisis menunjukkan bahwa terdapat hubungan yang positif dan rendah antara tingkat pendidikan dengan kepatuhan penggunan pil KB. Terdapat hubungan yang positif dan kuat antara tingkat pengetahuan dengan kepatuhan pengguna pil KB.

\section{KESIMPULAN}

1. Mayoritas tingkat pengetahuan tentang DBD masyarakat di Dukuh Karanganyar, Polokarto berada pada kategori tingkat pengetahuan tinggi sebanyak $96 \%$.

2. Tingkat pendidikan warga Dukuh Karanganyar sebagian besar masuk dalam kategori tingkat pendidikan lanjut sebanyak $65.3 \%$.

3. Upaya pencegahan DBD yang dilakukan warga Dukuh Karanganyar masih kurang efektif sebanyak $76 \%$.

4. Berdasarkan hasil uji regesi logistik dapat diketahui bahwa terdapat hubungan negatif signifikan secara statistik antara tingkat pendidikan dengan keefektifan upaya pencegahan DBD. Warga dengan tingkat pendidikan lanjut memiliki kemungkinan melakukan upaya pencegahan DBD secara efektif 0,034 kali lebih besar daripada warga dengan tingkat pendidikan wajib (OR=0.034; Cl 95\% 0.012 hingga $0.99 ; \mathrm{p}=0.000)$. Terdapat hubungan positif tidak signifikan secara statistik antara tingkat pengetahuan dan keefektifan upaya pencegahan DBD (OR=1.611; $\mathrm{Cl}$ 95\% 0.293 hingga 8.863; $p=0.584)$.

\section{SARAN}

1. Bagi masyarakat perlu meningkatkan motivasi, minat dan sikap/komponen afektif serta psikomotor dalam upaya pencegahan DBD.

2. Bagi Puskesmas perlu meningkatkan pendidikan kesehatan mengenai DBD pada warga.

3. Bagi peneliti selanjutnya disarankan untuk melakukan penelitian mengenai gambaran sikap warga Dukuh Karanganyar dalam upaya pencegahan DBD. 
DAFTAR PUSTAKA

Ambarwati, F., E. M. Sutrisna dan G. Setiyadi. 2013. Hubungan Tingkat Pendidikan dan Tingkat Pengetahuan dengan Kepatuhan Pengguna Pil KB di Kecamatan Weru Kabupaten Sukoharjo tahun 2013, Fakultas Farmasi UMS. Surakarta. Diakses tangal 30 Maret 2017.

Erfandi. 2009. Pengetahuan dan Faktor-faktor yang Mempengaruhi. http//:forbetterhealth.wordpress.c om/2009/04/19/html, 2009.

Fitriani, S. 2011. Promosi Kesehatan. Edisi 1. Graha IImu, Yogyakarta.

Hasbullah. 2009. Dasar-dasar IImu Pendidikan. Jakarta: Rajawali Pers.

Misnadiarly. 2009. Demam Berdarah Dengue (DBD). Pustaka Populer Obor, Jakarta.

Notoatmodjo, S. 2007. Promosi Kesehatan dan IImu Perilaku. PT Rineka Cipta, Jakarta.

Puspitasari, R. dan I. Susanto. 2011. Analisis Spasial Kasus Demam Berdarah di Sukoharjo Jawa Tengah dengan Menggunakan Indeks Moran, UNS Surakarta. Surakarta. Diakses tanggal 14 Oktober 2016.
Silowati, L. N., S. Arifah dan E. Zulaicha. 2012. Hubungan Tingkat Pengetahuan tentang Merokok terhadap Frekuensi Merokok pada Remaja Awal di Desa Gayam Kecamatan Sukoharjo Kabupaten Sukoharjo, Fakultas IImu Kesehatan UMS. Surakarta. Diakses tanggal 16 Agustus 2017

Slameto. 2015. Belajar dan FaktorFaktor yang Mempengaruhinya. Rineka Cipta, Jakarta.

Soegijanto, S. 2006. Demam Berdarah Dengue. Airlangga University Press, Surabaya.

${ }^{1}$ Dosen AKPER Panti Kosala

Surakarta

${ }^{2}$ Dosen AKPER Panti Kosala

Surakarta

${ }^{3}$ Mahasiswa AKPER Panti Kosala Surakarta 